\title{
Cross-Sectional and Medico-Legal Investigations of Covid-19 Response, Ghana
}

\author{
Ishmael D. Norman, Emmanuel D. Kpeglo, and Raymond Agalga
}

\section{ABSTRACT}

From the 12th of March 2020, Ghana took bold steps against Covid-19, aimed at controlling the spread among the population, protecting against community infections, treating those with the disease and ensuring public trust in the healthcare delivery system. This cross-sectional survey, assessed the effectiveness of Ghana's risk communication, legal framework and response approaches to the Covid-19 Pandemic.

The first part was a Cross-Sectional approach. The authors used data collected on-line via a self-reported questionnaire between 16th March and 16th April from [127] participants. Differences in mean scores and other factors associated with awareness; as a function of risk communication; to Covid-19, knowledge of safety protocols, and practices towards the disease, were conducted using univariate and multivariate data analytical methods. The second approach was a literature review of Ghana's legal framework existing prior to the outbreak of Covid-19 and those enacted by Parliament during the emergency period towards the management of the pandemic. A content analyses of the legal framework, to assess official compliance with the framework in relation to the aim of this study was conducted.

The majority of the study participants were knowledgeable about how Covid19 was transmitted. An independent samples t-test was performed to determine if a difference existed between the mean scores of COVID-19 knowledges for males and females. The outcome variable was found to be normally distributed and equal variances are assumed based upon results of Levene's test $(F(125)=0.097$, $p$-value $=0.756)$. There was no significant difference in knowledge scores (with minimum $=1$, and maximum $=3$ ) for males $($ mean $=1.61$, standard deviation $=0.665)$ and females $($ mean $=1.56$, standard deviation $=0.698 ; \mathrm{t}$ - value $\mathrm{t}(125)=0.374$, $\mathrm{p}$-value $=0.709$, twotailed). The magnitude of the difference in the means (mean difference $=$ $0.054,95 \%$ confidence interval: $-\mathbf{0 . 2 3 4}, \mathbf{0 . 3 4 3}$ ) and the effect size was very small (Cohen $d=0.08$ ). The independent samples t-test was also performed to test the hypothesis that males and females were associated with statistically significant different COVID-19 awareness mean scores. The test showed no significant difference in the awareness scores for males and females. The results from the content analyses of the legal framework show there was lax adherence of government to the legal framework for Pandemic response on these dimensions: Planning and Coordination; Surveillance, Situation monitoring and Assessment; Prevention, Containment and Management; Communications; and Social Mitigation. It further shows that neither the existing legislation nor the Executive Instruments, E. I. 63 - 66, and 164 directed at Covid-19 administrative and epidemiologic controls, have helped to stop the spread of Covid-19, considering the uptick of new infections of Covid-19.

Covid-19 has exposed the lack of effective risk communication modalities in Ghana and the government's lack of adherence to the legal framework on disasters and emergencies in general, a vacuum which is filled by social media.

Keywords: Risk Communication for Covid-19; Knowledge, Awareness and Practices; Legal framework.

\section{INTRODUCTION}

The coronavirus disease of 2019 was christened Covid-19 by the World Health Organization, WHO in March of 2020.
Published Online: November 30, 2020 ISSN: $2593-8339$

DOI: $10.24018 /$ ejmed.2020.2.6.587

Ishmael D. Norman

Administration, Institute for Security, Disaster and Emergency Studies, Ghana.

(e-mail: ishmael.norman@yahoo.com) Emmanuel D. Kpeglo

Department of Criminology, Institute for Security, Disaster and Emergency Studies, Ghana.

(e-mail: kpaglo@yahoo.com)

Raymond Agalga*

Ghana Atomic Energy Commission, Ghana.

(e-mail: agalrd@gmail.com)

*Corresponding Author 
Respiratory Syndrome coronavirus 2 (SARS-CoV-2) [4]. It belongs to the family of ribonucleic acid (RNA) viruses that are zoonotic and can be transmitted from animals such as bats, cattle, cats and camels. It can lead to the common cold, and other diseases such as the Middle East Respiratory Syndrome (MERS-CoV). The symptoms of Covid-19, include fever, dry cough, fatigue, pneumonia, general feeling of un-wellness, shortness of breath and kidney failure. Internationally, the mortality rate is around $4 \%$ but nationally, the mortality rate, ranges from $0.56 \%$ to $0.62 \%$ [1], [2]. The most vulnerable are those with pre-existing chronic diseases of the heart, diabetes, and lungs, which are described as comorbidities, together with the elderly persons [3], [4].

Covid-19 was first discovered in December of 2019, in Wuhan, a province of Hubei [3], [6]. The first confirmed case in Africa was in Egypt on the 14th of February 2020. Ghana had its first two confirmed cases on 12th March 2020, both of which were imported by foreign travelers [6]. On 15th March, the government of Ghana, under the Declaration of Public Health Emergency (Coronavirus Covid-19 Pandemic) E. I. 61 mandate, consistent with the Public Health Act, 2012 (Act 851) Sections 169 and 170, the Minister of Health declared a public health emergency. The government initiated a 5-prong attack thus: "(i) limit and stop the importation of the virus, (ii) contain its spread, (iii) provide adequate care for the sick, (iv) limit the impact of the virus on social and economic life, and (v) use the opportunity afforded by the emergency to expand our domestic capability and deepen our self-reliance" [5]. The new pandemic response approach made no reference or implied the existing national response plan on the pandemic. In addition to the new national response plans articulated, sometimes, in ad hoc manner to the pandemic, Ghana passed a number of new legislations and issued a series of Executive Instruments, all aimed at curbing and controlling the pandemic.

These were, the (i) Establishment of Emergency Communication System Instrument, 2020, under Executive Instrument, E. I. 63; (ii) Imposition of Restrictions Act of 2020, (Act 1012) on the 21st March, 2020, with its implementing provision under (iii) Executive Instrument, E. I. 64 and 65, 2020. These were followed by (iv) Executive Instrument, E. I. 66 issued to extended the lock-down period under E. I. 64. These were meant to buttress the reach of existing legislation such as the Public Health Act, 2012 (Act 851), the Emergency Powers Act of 1994, and in consonance with the 1992 Constitution of Ghana. Under the combined authority of these pieces of legislations and executive instruments, the government suspended all inbound and outbound flights, imposed restrictions on select cities in Ghana, namely, Greater Accra and Kasoa and Greater Kumasi. The rest of the nation was not placed under restrictions. All universities, both public and private, Churches and Mosques as well as basic schools in the nation were all shut down. Markets, Malls and Supermarkets, pharmacies and trading centers, together with public transport were not shut down, even within the lockdown cities and towns. Several social mitigation programs were introduced by the government, including the supply of potable water by tanker loads to communities that had no access to pipe borne water in the city of Accra and its environs and in deprived suburbs in Greater Kumasi. Food on wheels was delivered to the vulnerable and at-risk populations also within the lockdown areas.

As the confirmed cases continued to climb despite the restrictions on movement and other activities, the government raised (v) Executive Instrument 164. E. I. 164, which came into force on June 15, 2020, made it a crime for people who fail to wear face masks in public. They would be committing an offence that carries a prison sentence of four to 10 years or a fine of $\mathrm{GH} \notin 12,000$ [USD\$1,791] to $\mathrm{GH} \notin 60,000$, [USD\$8,955] or both. This was to continue for three months.

Each and every one of the government's 5-step attack was dependent on the knowledge and awareness of the population to the pandemic, the nature and appropriateness of the risk communication and public education, adherence to both the WHO and national hygienic protocols such as face-mask wearing, hand-washing, the use of hand sanitizers, coughing into one's elbow sleeve, physical distancing of at least one meter as well as the enforcement of the legislative framework during the lock-down (WHO, Hand Hygiene, 2020; Country $\&$ Technical Guidance-Coronavirus disease (Covid-19), 29/3/2020).

Risk communication envisions a system encompassing the actual communication of imminent danger to the community and early warning system, such as what Covid-19 pandemic called for [8]-[11]. The concept of risk perception deals with the overall awareness and knowledge surrounding a particular contingency or threat. The risk perception of a body politic such as Ghana is established through learned social patterns and cultural relationships to risk [12], [8], [13]. That is to say, there is a relationship between psychosocial background and risk perception [14], [15]. Due to the sudden outbreak of Covid-19, and perhaps, due to the deep penetration of social media, the literature appears to support the theory that, the general public may have been sufficiently become aware or had knowledge of the novel coronavirus disease even before the central government began its deliberate risk communication against Covid-19 with respect to personal protection, mode of transmission, and the adherence to social etiquette.

The legal architecture for pandemic and health emergency response appears to have been muddled with the new legal strategies adopted by the central government. The Emergency Powers Act of 1994, (Act 472) seems to have provided a more direct pathway to the initiation of the imposition of restrictions, without the need to enact another legislation for the same purpose. The Emergency Powers Act definition of the state of emergency is that, "Disaster means any occurrence by which there is a serious disruption of general safety endangering the life and health of many people or large material interests which requires coordinated action by services of different disciplines and includes floods, earthquakes, drought, rainstorm, war, civil strife, and industrial accidents". Covid-19 is one of such situations which the Act describes.

The Imposition of Restrictions Act of 2020, (Act 1012) did not materially add deeper level of restrictions on civil liberties and neither did the Executive Instruments, E. I. 64 and 65. The outbreak of Covid-19, appears to have been one of those situations Ghana, where the declaration of a state of emergency would have been consistent with the legal framework and the constitutional mandate. 
This study assessed the national risk communication strategy to assess knowledge, awareness, and practices as integral parts of the response approaches for Covid-19. It took into consideration the legal construct on which the aims of the national risk communication and response protocol were meant to be realized. This is the first study in Ghana, probably in Africa, to the best of the authors' knowledge and research, on knowledge, awareness, practices and the effectiveness of risk communication and response vis-à-vis the legal framework against Covid-19.

\section{METHODS}

\section{A. Sample Size}

The authors used data collected on-line via a self-reported questionnaire between 16th March and 16th April from [127] participants. Differences in mean scores and other factors associated with awareness; risk communication to Covid-19, knowledge of safety protocols, and practices towards the disease were conducted using univariate and multivariate data analytical methods.

\section{B. Study Design and Preparation of Questionnaire}

This cross-sectional study was conducted between 16th March and 16th April, 2020, among the population of Ghana, using Google's On-line survey platform for the administration of the questionnaire due to the Imposition of Restrictions, E. I. 64 of the same period. Ethical clearance for this study was sort from the Research and Ethical Committee of the Institute for Security, Disaster and Emergency Studies. The study was conducted among 127 from purposively selected social media platforms, where all the authors were members in Ghana. The membership of those platforms consisted of government and private sector employees, informal workers, and university students and lecturers. Ghana had its two first confirmed Covid-19 cases on 12th March, 2020. On 15th March, 2020, a Partial Lockdown in Greater Accra and Kumasi, two metropolises with about a third of the national population of 30 million. The questionnaire was prepared in the English Language. The first part of the questionnaire involved an introduction showing the objectives of the study and highlighting that participation in this study was voluntary and that the answers would be treated confidentially. Participants were not offered any financial compensation. The completion of the online survey took about 8-10 min and included multiple-choice questions, or yes/no/ I don't know options within different sections. A second section determined the sociodemographic variables of the participants including gender, age, university, location, major field of study, education level, and religion as well as geographical location. The other sections measured the participants' knowledge about COVID-19, such as mode of transmission, hygienic and safety protocols, government interventions, and symptoms. Another section explored the source they used for information about COVID-19.

\section{Consistency and Validation of Questionnaire}

The questionnaire was prepared based on the available information on the web sites of the Ghana Health Service, Ministry of Health, Ghana and the American Centers for Disease Control, CDC respectively and the World Health
Organization (WHO) as well as Ghana's 2009-2013 Integrated Strategic Response Plan for Pandemic Influenza. The questionnaire was reviewed internally, and by several public health experts. It was revised based on their comments. It was pilot tested among a select group of participants to evaluate the internal consistency and validity of the questions and to estimate the time for completion.

\section{Method for Data Analysis}

The study employed univariate and multivariate data analytical methods. SPSS software (IBM Statistics 23) was used to tabulate the frequency of all the questions using both numbers and percentages. One-way analysis of variance (ANOVA) was used to assess differences in mean values for knowledge, and awareness in terms of risk communication, and response. The assessment measured the variables of knowledge, and awareness of COVID-19 across males and females, and different age groups. Due to the small size of the sample, N-127, independent samples t-test was performed to determine if a difference existed between the mean scores of knowledge, and awareness of COVID-19 based on gender, and age. This was followed by a multivariate linear regression analysis to identify factors related to knowledge, awareness, practices, risk communications, and response.

\section{E. Content Analysis of Legal the Legal Framework on Covid-19}

Authors read and briefed each of the specific legislations enacted to respond to Covid-19, to identify the effect of the law on achieving the cardinal aim of government's initiated 5-prong attack against Covid-19. The following are the five pillars of the national Covid-19 intervention program: (i) limit and stop the importation of the virus, (ii) contain its spread, (iii) provide adequate care for the sick, (iv) limit the impact of the virus on social and economic life, and (v) use the opportunity afforded by the emergency to expand our domestic capability and deepen our self-reliance [5]. The laws that were read and briefed are the following: (a) Establishment of Emergency Communication System Instrument, 2020, under Executive Instrument, E. I. 63; (b) Imposition of Restrictions Act of 2020, (Act 1012) on the 21st March, 2020, with its implementing provision under (c and d) Executive Instrument, E. I. 64 and 65, 2020. These were followed by (e) Executive Instrument, E. I. 66 issued to extended the lock-down period under E. I. 64. These were meant to buttress the reach of existing legislation such as the (f) Public Health Act, 2012 (Act 851), the (g) Emergency Powers Act of 1994, and in consonance with the 1992 Constitution of Ghana. The authors' recorded the pertinent portions of the law on the dimensions of this study and reported those portions in the results, based on the authors skills, knowledge and training in public health, law and policy analysis.

\section{RESULTS}

A. Self-reported Online Survey between 16th April and 16th May, 2020 Demographic Characteristics

The national online survey reported here was opened to all. The male participants were $78.7 \%$ while only $21.3 \%$ were female. Considering that $93.7 \%$ of the respondents had HND; 
Bachelor/Masters/Ph.D. education, the low participation of females is a concern. Please see Table 1. Out of the sixteen (16) administrative districts in Ghana, respondents from twelve (12) districts participated in the study.

TABLE I: SELF-REPORTED ONLINE SURVEY BETWEEN $16^{\mathrm{TH}}$ APRIL AND $16^{\mathrm{TH}}$ MAY 2020

\begin{tabular}{lc}
\hline \multicolumn{1}{c}{ Characteristic } & $\begin{array}{c}\text { Number }(\%) \\
\mathbf{N}=\mathbf{1 2 7}\end{array}$ \\
\hline Age group, yrs. & \\
$<30$ & $24(18.9)$ \\
$31-40$ & $64(50.4)$ \\
$41-50$ & $25(19.7)$ \\
$>51$ & $14(11.0)$ \\
Gender & \\
Male & $100(78.7)$ \\
Female & $27(21.3)$ \\
Religion & \\
Christian & $115(90.6)$ \\
Moslem & $7(5.5)$ \\
Traditional & $2(1.6)$ \\
Non-religious & $1(0.8)$ \\
None & $2(1.6)$ \\
Region & \\
Greater Accra & $58(45.7)$ \\
Ashanti & $9(7.1)$ \\
Upper East & $20(15.7)$ \\
Upper West & $1(0.8)$ \\
Northern & $4(3.1)$ \\
Savannah & $1(0.8)$ \\
Oti & $1(0.8)$ \\
Volta & $21(16.5)$ \\
Bono & $2(1.6)$ \\
Western & $3(2.4)$ \\
Central & $5(3.9)$ \\
Eastern & $2(1.6)$ \\
Primary & \\
Junior High School & $0(0.0)$ \\
Senior High School/A-level & $0(0.0)$ \\
Degree & $8(6.3)$ \\
& $119(93.7)$ \\
\hline
\end{tabular}

B. COVID-19 Risk Communication and Response Evaluation (Responses), Attitudes, Knowledge, Awareness and Preparedness

The cohort reported that overall perception of risk before the Covid-19 Pandemic was relatively high with $60.6 \%$ while "low risk" to "No risk" was $15.7 \%$ and $1.6 \%$ respectively (Table 2). This development could be attributed to the widespread use of mobile phones and access to other telephonic services and the Internet. These variables changed after the introduction of public education and health promotion by the government on the Covid-19 to $42.5 \%$ for "High" risk perception as opposed to the previous $60.6 \%$. However, the cohort that entertained "Moderate" risk perception improved from the previous $22.2 \%$ to $41.7 \%$. This may be explained with the acquisition of knowledge, awareness and practices, KAP of the burden the disease could pose to their health-seeking behaviors. Among the respondents in Ghana, cohort of (127), 31.5\% knew corona virus to be a disease-causing agent, and with another $97.6 \%$ knowing or having an idea about how the disease is transmitted as reported in Table 2 below. Specifically, $87.4 \%$ said (contact within infected person), $84.8 \%$ knew (contact with 'infected' surfaces) where droplets and contact from and with an infected person may have been made. The KAP on transmission found $87.4 \%$ knew transmission was from 'droplets of saliva or discharge from nose' or month.
TABLE II: COVID-19 RISK COMMUNICATION AND RESPONSE Evaluation (Responses), AtTITUdes, KNOWLEDGE, AwARENESS, AND PREPAREDNESS

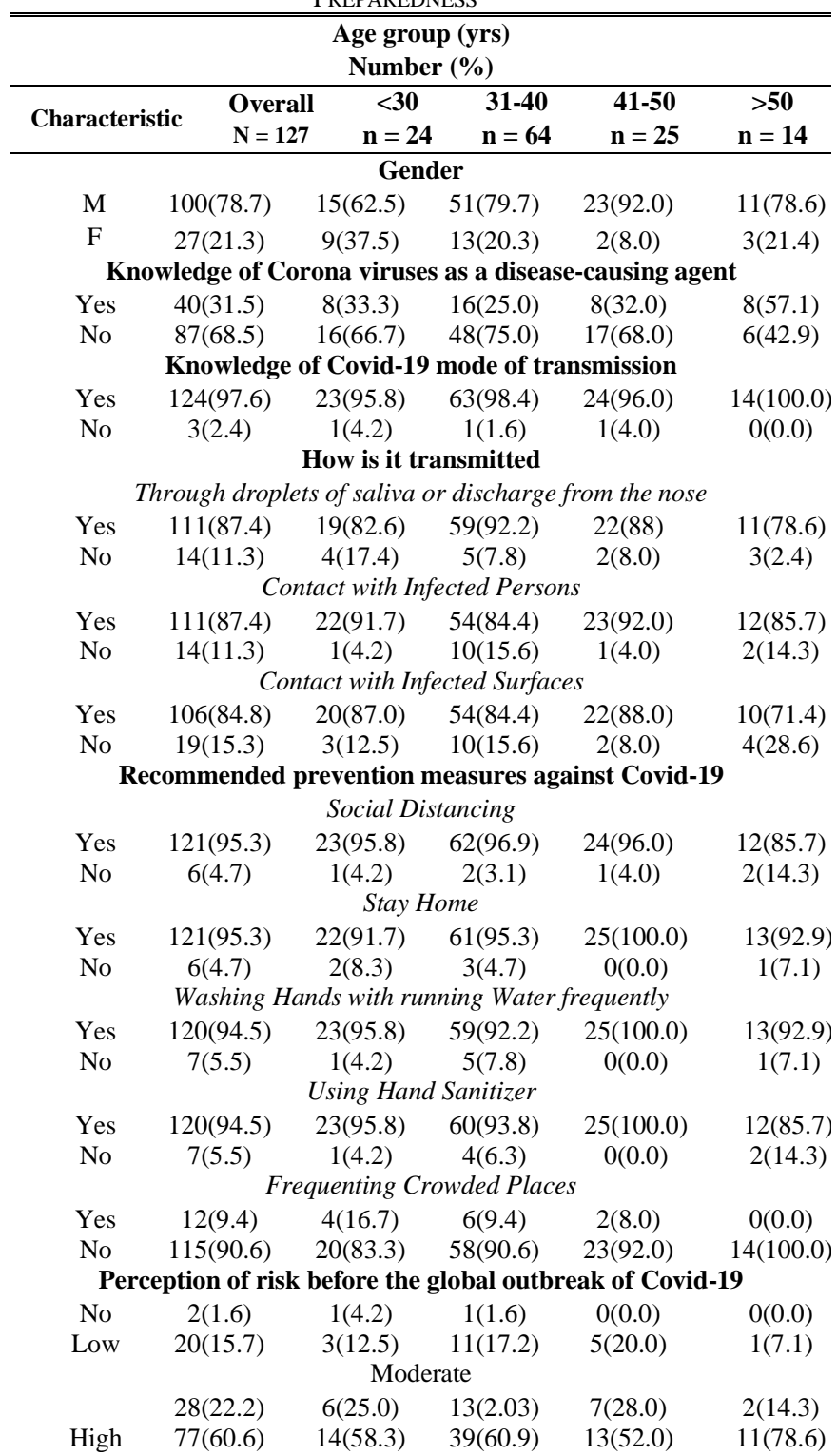

Current perception of risk after interventions by the Government of

$$
\text { Ghana }
$$

\begin{tabular}{cccccc} 
No & $1(0.8)$ & $0(0.0)$ & $1(1.6)$ & $0(0.0)$ & $0(0.0)$ \\
Low & $19(15.0)$ & $3(12.5)$ & $9(14.1)$ & $4(16.0)$ & $3(21.4)$ \\
& \multicolumn{5}{c}{ Moderate } \\
High & $53(41.7)$ & $9(37.5)$ & $31(48.4)$ & $11(44.0)$ & $2(14.3)$ \\
& $54(42.5)$ & $12(50.0)$ & $23(35.9)$ & $10(40.0)$ & $9(64.3)$
\end{tabular}

The preparedness of the Government of Ghana following the

notification of the first case of COVID-19 in Ghana was timely

$\begin{array}{llllll}\text { Yes } & 40(31.5) & 9(37.5) & 19(29.7) & 8(32.2) & 4(28.6)\end{array}$

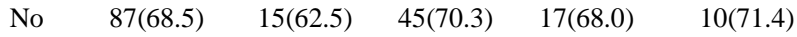

The preparedness of the Government of Ghana following the

notification of the first case of COVID-19 in Ghana was adequate

$\begin{array}{llllll}\text { Yes } & 23(18.1) & 6(25.0) & 12(18.8) & 2(8.0) & 3(21.4)\end{array}$

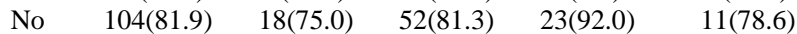

If NO, what was missing in the preparedness of the Government of

$$
\text { Ghana. }
$$

\begin{tabular}{cccccc}
\multicolumn{5}{c}{ Government was not prepared } \\
Yes & $79(62.2)$ & $15(62.5)$ & $40(62.5)$ & $19(76.0)$ & $5(25.7)$ \\
No & $28(22.0)$ & $4(1.7)$ & $12(18.8)$ & $5(20.0)$ & $7(50.0)$ \\
Government underestimated the risk \\
Yes & $81(63.8)$ & $16(67.0)$ & $42(65.6)$ & $16(64.0)$ & $7(50.0)$ \\
No & $26(20.5)$ & $3(12.5)$ & $10(15.6)$ & $8(32.0)$ & $5(35.7)$ \\
Education & not comprehensively taken into consideration the societal \\
Yes & $73(57.5)$ & $9(37.5)$ & $38(59.4)$ & $17(68.0)$ & $9(64.3)$ \\
No & $34(26.8)$ & $10(41.7)$ & $14(21.9)$ & $7(28.0)$ & $3(21.4)$
\end{tabular}


Education was not carried out in a timely manner

$\begin{array}{lccccc}\text { Yes } & 74(58.3) & 10(41.7) & 39(60.9) & 18(72.0) & 7(50.0) \\ \text { No } & 33(26.0) & 9(37.5) & 13(20.3) & 6(24.0) & 5(35.7)\end{array}$

Government over-relied on Systems and structures put in place for the

\begin{tabular}{cccccc}
\multicolumn{5}{c}{ Ebola Outbreak } \\
Yes & $9(7.1)$ & $2(8.3)$ & $4(6.3)$ & $3(12.0)$ & $0(0.0)$ \\
No & $98(77.2)$ & $17(70.8)$ & $48(75.0)$ & $21(84.0)$ & $12(85.7)$
\end{tabular}

Measures put in place by the Government of Ghana in response to the Covid-19 in Ghana were adequate

$\begin{array}{llllll}\text { Yes } & 39(30.7) & 12(50.0) & 18(28.1) & 4(16.0) & 5(35.7)\end{array}$ $\begin{array}{lllll}\text { No } & 88(69.3) & 12(50.0) & 46(71.9) & 21(84.0)\end{array}$

If NO, what was missing in measures put in place by Government of Ghana in response to the Covid-19

I expected a much timely response

\begin{tabular}{|c|c|c|c|c|c|}
\hline Yes & $44(34.6)$ & $6(25.0)$ & $22(34.4)$ & $11(44.0)$ & $5(35.7)$ \\
\hline No & $44(34.6)$ & $7(29.2)$ & $23(35.9)$ & $10(40.0)$ & $4(28.6)$ \\
\hline \multicolumn{6}{|c|}{ Governments response is saddled with politics } \\
\hline Yes & $42(33.1)$ & $9(37.5)$ & $20(31.3)$ & $10(40.0)$ & $3(21.4)$ \\
\hline No & $46(36.2)$ & $4(16.7)$ & $25(39.1)$ & $11(44.0)$ & $6(42.9)$ \\
\hline \multicolumn{6}{|c|}{ The risk was underestimated } \\
\hline Yes & $31(24.4)$ & $4(16.7)$ & $16(25.0)$ & $9(36.0)$ & 2(14.3) \\
\hline No & $57(44.9)$ & $9(37.5)$ & $29(45.3)$ & 12( & $7(50.0)$ \\
\hline \multicolumn{6}{|c|}{ Response measures not adequate } \\
\hline Yes & $34(26.8)$ & $8(33.3)$ & $12(18.8)$ & 11(44.0) & $3(21.4)$ \\
\hline No & $54(42.5)$ & $8(33.3)$ & $33(51.6)$ & $10(40.0)$ & $6(42.9)$ \\
\hline \multicolumn{6}{|c|}{ Press Briefings by the Ministry of Health and other relevant } \\
\hline \multicolumn{6}{|c|}{$\begin{array}{l}\text { stakeholders on the Covid-19 pandemic have been useful in clearly } \\
\text { defining the situation both globally and locally }\end{array}$} \\
\hline Yes & $85(66.9)$ & $16(66.7)$ & $42(65.6)$ & $16(64.0)$ & $11(78.6$ \\
\hline No & $42(33.1)$ & $8(33.3)$ & $22(34.4)$ & $9(36.0)$ & $3(2$ \\
\hline & \multicolumn{5}{|c|}{ If NO, what was missing in the press briefings? } \\
\hline Yes & $23(18.1)$ & $4(16.7)$ & $12(18.8)$ & $6(24.0)$ & $1(7.1)$ \\
\hline No & $23(18.1)$ & $5(20.8)$ & $13(20.3)$ & $3(12.0)$ & $2(14.2)$ \\
\hline \multicolumn{6}{|c|}{ Government communications are not transparent } \\
\hline Yes & $29(22.8)$ & $5(20.8)$ & $17(26.6)$ & $5(20.0)$ & 2(14.2) \\
\hline No & $17(13.4)$ & $4(16.7)$ & $8(12.5)$ & $4(16.0)$ & $1(7.1)$ \\
\hline \multicolumn{6}{|c|}{ Conflicting explanations were given } \\
\hline Yes & $20(15.7)$ & $3(12.5)$ & $13(20.3)$ & $3(12.0)$ & $1(7.1)$ \\
\hline No & $26(20.5)$ & $6(25.0)$ & $12(18.8)$ & $6(24.0)$ & 2(14.2) \\
\hline \multicolumn{6}{|c|}{ I expected a much frequent engagement } \\
\hline Yes & $18(14.2)$ & $3(12.5)$ & $8(12.5)$ & $5(20.0)$ & 2(14.2) \\
\hline No & $28(22.0)$ & $6(25.0)$ & $17(26.6)$ & $4(16.0)$ & $1(7.1)$ \\
\hline \multicolumn{6}{|c|}{ The risk was underestimated } \\
\hline Yes & $17(13.4)$ & $4(16.7)$ & $8(12.5)$ & $4(16.0)$ & $1(7.1)$ \\
\hline No & $29(22.8)$ & $5(20.8)$ & $17(26.6)$ & $5(20.0)$ & 2(14.2) \\
\hline
\end{tabular}

The aspect of this pandemic outbreak that causes the greatest concern?

The nature of the disease

\begin{tabular}{llllll} 
Yes & $75(59.1)$ & $11(45.8)$ & $38(59.4)$ & $14(56.0)$ & $12(85.7)$ \\
No & $52(40.9)$ & $13(54.2)$ & $26(40.6)$ & $11(44.0)$ & $2(14.3)$ \\
\multicolumn{7}{c}{ The fact that the cases are increasing in Ghana } \\
Yes & $70(55.1)$ & $16(66.7)$ & $35(54.7)$ & $15(60.0)$ & $4(28.6)$ \\
No & $57(44.8)$ & $8(33.3)$ & $29(45.3)$ & $10(40.0)$ & $10(71.4)$ \\
The number of notified cases \\
Yes & $35(27.6)$ & $7(29.2)$ & $19(29.7)$ & $6(24.0)$ & $3(21.4)$ \\
No & $92(72.4)$ & $17(70.8)$ & $45(70.3)$ & $19(76.0)$ & $11(78.6)$ \\
Yes & $44(34.6)$ & $7(29.2)$ & $26(40.6)$ & $7(28.0)$ & $4(28.6)$ \\
No & $83(65.4)$ & $17(70.8)$ & $38(59.4)$ & $18(72.0)$ & $10(71.4)$
\end{tabular}

Preferred source of information used to find out about the Covid-19 pandemic and its possible consequences.

Social Media (Facebook, Twitter, etc.)

$\begin{array}{lllll}\text { Yes } & 62(48.8) & 15(62.5) & 30(46.9) & 14(56.0)\end{array}$

No $\quad 65(51.2) \quad 9(37.5) \quad 34(53.1) \quad 11(44.0)$ Television and newspapers

Yes $\quad 68(53.5) \quad 12(50.0) \quad 35(54.7) \quad 15(60.0)$

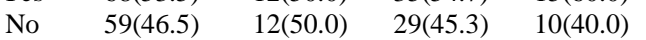

NCCE and local radio station and also the use of the chiefs

$\begin{array}{lcccc}\text { Yes } & 2(1.6) & 0(0.0) & 2(3.1) & 0(0.0) \\ & 125(98.4) & 24(100.0) & 62(96.9) & 25(100.0\end{array}$

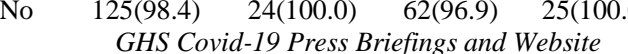

$\begin{array}{lllll}\text { Yes } & 76(59.8) & 15(62.5) & 35(54.7) & 14(56.0)\end{array}$

$\begin{array}{llll}\text { No } & 51(40.2) \quad 9(37.5) & 29(45.3) & 11(44.0)\end{array}$ Search on specialized websites

Yes $\quad 29(22.8) \quad 7(29.2) \quad 11 \mid(17.2) \quad 9(36.0)$

$\begin{array}{llll}\text { No } & 98(77.2) \quad 17(70.8) \quad 53(82.8) & 16(64.0)\end{array}$
Institutional websites (WHO, John Hopkins University, etc.)

$\begin{array}{llllll}\text { Yes } & 63(49.6) & 10(41.7) & 29(45.3) & 15(60.0) & 9(64.3)\end{array}$

$\begin{array}{lllll}\text { No } & 64(50.4) & 14(58.3) & 35(54.7) & 10(40.0)\end{array}$

Availability of sufficient ventilators for those critically ill from Covid-19

$\begin{array}{llllll}\text { Yes } & 15(11.8) & 1(4.2) & 10(15.6) & 1(4.0) & 3(21.4)\end{array}$

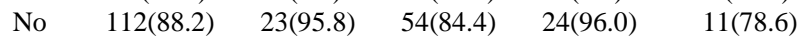

Is the government of Ghana doing a good job in quarantining and isolating travelers into Ghana at expensive hotels?

$\begin{array}{llllll}\text { Yes } & 60(47.2) & 12(50.0) & 30(46.9) & 10(40.0) & 8(57.1)\end{array}$

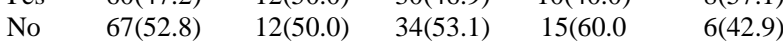

Should they have been quarantined in student hotels such as at University of Ghana to cut costs to the nation?

$\begin{array}{llllll}\text { Yes } & 77(60.6) & 12(50.0) & 40(62.5) & 15(60.0) & 10(71.4)\end{array}$

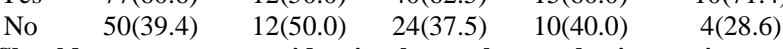

Should government provide stimulus package to businesses in general?

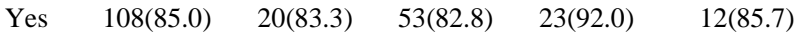

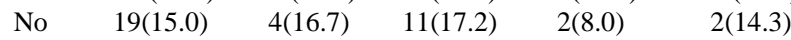

Assessment of government's intervention to feed the needy and vulnerable in the Lockdown areas.

It is a waste of national resources

18(14.2) 3(12.5) $\quad 8(12.5) \quad 4(16.0)$

It is a laudable and good intervention

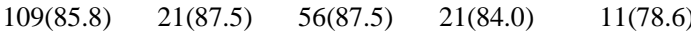

What do you think would happen to the feeding program should the disease be within Ghana till the end of June? It will be Continued

54(42.5) $\quad 10(41.7) \quad 24(37.5) \quad 12(48.0) \quad 8(57.1)$ It will be Discontinued

45(35.4) 8(33.3) 26(40.6) $\quad 7(28.0) \quad 4(28.6)$

It will be farm out to private operators and philanthropist. $28(22.0) \quad 6(25.0) \quad 14(21.9) \quad 6(24.0) \quad 2(14.3)$

Was the deployment of the Ghana Police and Army personnel in line with public health emergency intervention?

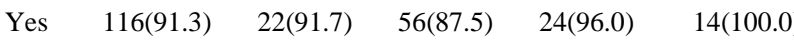

$\begin{array}{lllll}\text { No } & 11(8.7) & 2(8.3) & 8(12.5) & 1(4.0)\end{array} \quad 0(0.0)$

Was it wrong for the police and the army to carry weapons for such duties?

$\begin{array}{llllll}\text { Yes } & 47(37.0) & 6(25.0) & 24(37.5) & 10(40.0) & 7(50.0)\end{array}$

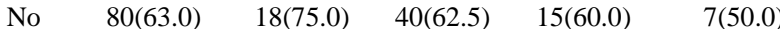

Do you think public confrontations with the security in the lockdown areas where preventable?

$\begin{array}{llllll}\text { Yes } & 80(63.0) & 8(33.3) & 45(70.3) & 16(64.0) & 11(78.6)\end{array}$

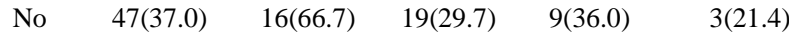

Do you think, your religious beliefs influence your perception of Covid-19 disease?

$\begin{array}{llllll}\text { Yes } & 33(26.0) & 9(37.5) & 16(25.0) & 5(20.0) & 3(21.4)\end{array}$

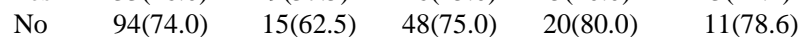

If yes, how would you assess the impact of your religion on your perception of Covid-19?

Negatively, confused as to who is speaking the right things $\begin{array}{lllll}3(2.4) & 1(4.2) & 2(3.1) & 0(0.0) & 0(0.0)\end{array}$

Positively, giving me a clearer understanding of what is at stake $\begin{array}{lllll}33(26.0) & 7(29.2) & 17(26.6) & 6(24.0) & 3(21.4)\end{array}$

Overall, $95.3 \%$ of the respondents agreed with the "Stay home" recommendation of public health officials, with the same cohort endorsing "Social Distancing" protocol. The 3(21.4) number of cohorts that endorsed "Washing hands with

11(78.6) running water frequently" was $94.5 \%$, and also those $6(42.8)$ observing the "use of hand sanitizer" recording $94.5 \%$ of the 8(57.1) cohort. The result was also encouraging with respect to "frequenting crowded places", where only $9.4 \%$ overall, did $0(0.0)$ not observe this protocol. The majority of the cohort, $90.6 \%$ 14(100.C overall did not frequent crowded places. This may account 12(85.7) for the high level of education of the cohort.

2(14.3) In assessing knowledge and awareness of Covid-19 among 2(14.3) the study participants, it was noticed that those aged within 12(85.7) 31 and 40 years displayed higher levels of "knowledge" of 
Covid-19 compared to those less or above this cohort.

The same group of respondents between 31 and 40 years showed the greatest "awareness" of Covid-19 with $69.2 \%$ of them having a high level of awareness within the respective groups as shown in Tables 3 and 4. The disparity may be explained by the fact the group, perhaps, that cohort is relatively more youthful, are better educated and have, perhaps, better access to web-based information through their independent research or search for information on Covid-19.
It may also be that risk communication lacked behind in government's intervention efforts at the initial stages. Those who were less than 30 years in age, registered only $18.1 \%$ high awareness of Covid-19. Interestingly, those greater than 50 years in age, also showed low "high awareness" of $9.6 \%$. These outcomes in their cases demand more targeted public education on the diseases.

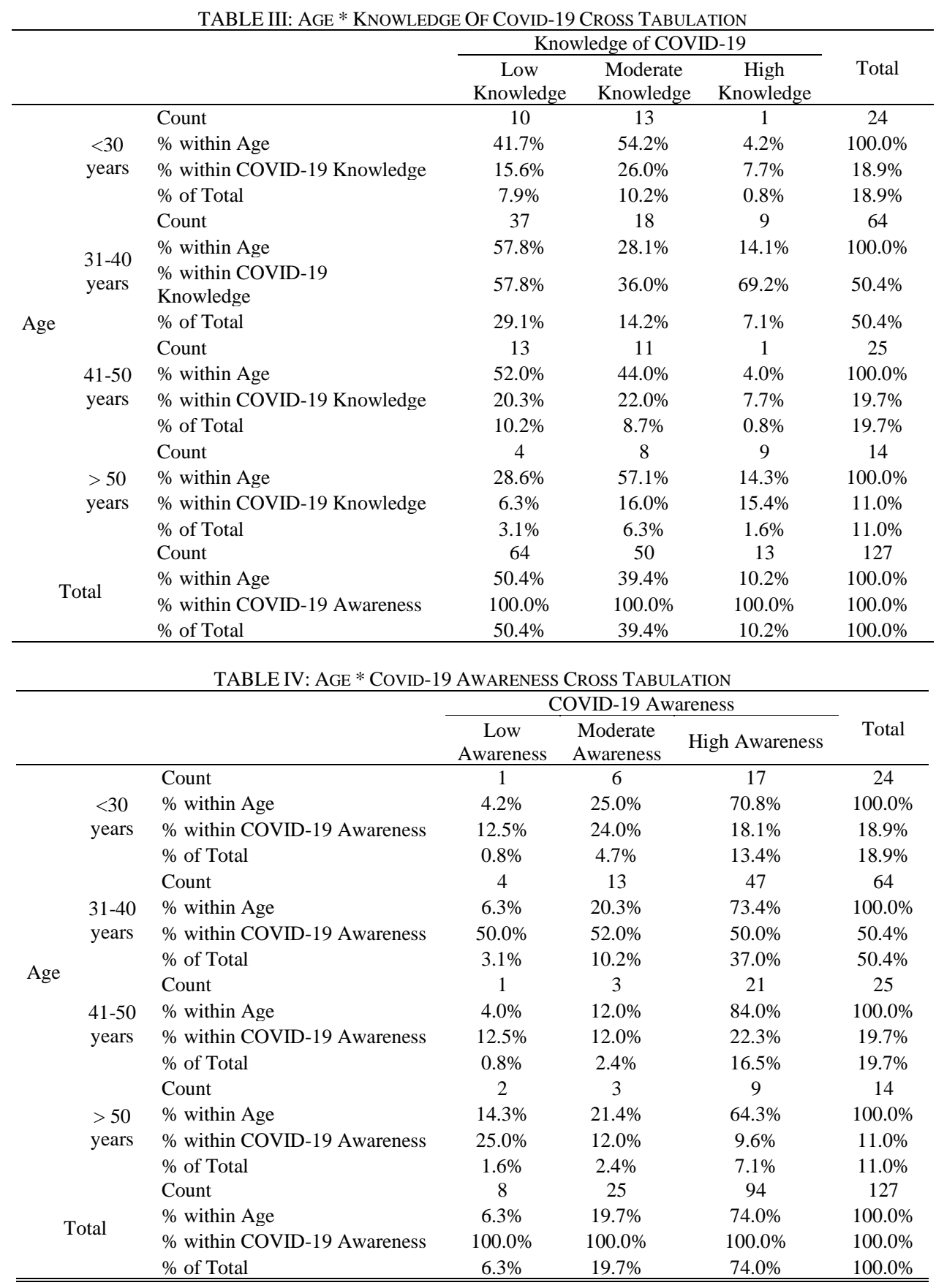

Cross-tabulation of gender to knowledge showed that among the males, $76.9 \%$ had "high knowledge" of Covid-19 as compared to $23.1 \%$ of females. This persisted at the low and moderate levels of knowledge for gender. The total percentage of males with "high awareness" was $79.8 \%$ while the females had only $20.20 \%$ in Table 5.

In terms of "awareness" between males and females, whereas males appeared to be relatively better aware of Covid-19, with $79.8 \%$ at the highest level of awareness, females had $20.2 \%$ at the highest level. More females $25.9 \%$ were moderately aware of the disease compared to only $18.0 \%$ of males. 
TABLE V: GENDER * KNOWLEDGE OF COVID-19 CROSS TABULATION

\begin{tabular}{|c|c|c|c|c|c|}
\hline & \multicolumn{3}{|c|}{ Knowledge of COVID-19 } & \multirow{2}{*}{ Total } \\
\hline & & Low & Moderate & High & \\
\hline \multirow{7}{*}{ Gender } & Count & 49 & 41 & 10 & 100 \\
\hline & & $49.0 \%$ & $41.0 \%$ & $10.0 \%$ & $100.0 \%$ \\
\hline & $\%$ within & & & & \\
\hline & $\begin{array}{c}\text { Knowledge } \\
\text { of COVID- } \\
19\end{array}$ & $76.6 \%$ & $82.0 \%$ & $76.9 \%$ & $78.7 \%$ \\
\hline & $\%$ of Total & $38.6 \%$ & $32.3 \%$ & $7.9 \%$ & $78.7 \%$ \\
\hline & Count & 15 & 9 & 3 & 27 \\
\hline & $\begin{array}{c}\% \text { within } \\
\text { Gender }\end{array}$ & $55.6 \%$ & $33.3 \%$ & $11.1 \%$ & $100.0 \%$ \\
\hline \multirow[t]{4}{*}{ Female } & $\begin{array}{l}\% \text { within } \\
\text { Knowledge }\end{array}$ & & & & \\
\hline & $\begin{array}{c}\text { of COVID- } \\
19\end{array}$ & $23.4 \%$ & $18.0 \%$ & $23.1 \%$ & $21.3 \%$ \\
\hline & $\%$ of Total & $\begin{array}{c}11.8 \% \\
64\end{array}$ & $\begin{array}{c}7.1 \% \\
50\end{array}$ & $2.4 \%$ & $\begin{array}{c}21.3 \% \\
127\end{array}$ \\
\hline & $\begin{array}{l}\% \text { within } \\
\text { Gender }\end{array}$ & $50.4 \%$ & $39.4 \%$ & $10.2 \%$ & $100.0 \%$ \\
\hline \multirow{3}{*}{ Total } & $\%$ within & & & & \\
\hline & $\begin{array}{c}\text { Knowledge } \\
\text { of COVID- } \\
19\end{array}$ & $100.0 \%$ & $100.0 \%$ & $100.0 \%$ & $100.0 \%$ \\
\hline & $\%$ of Total & $50.4 \%$ & $39.4 \%$ & $10.2 \%$ & $100.0 \%$ \\
\hline
\end{tabular}

TABEL VI: GENDER * COVID-19 AWARENESS CROSS TABULATION

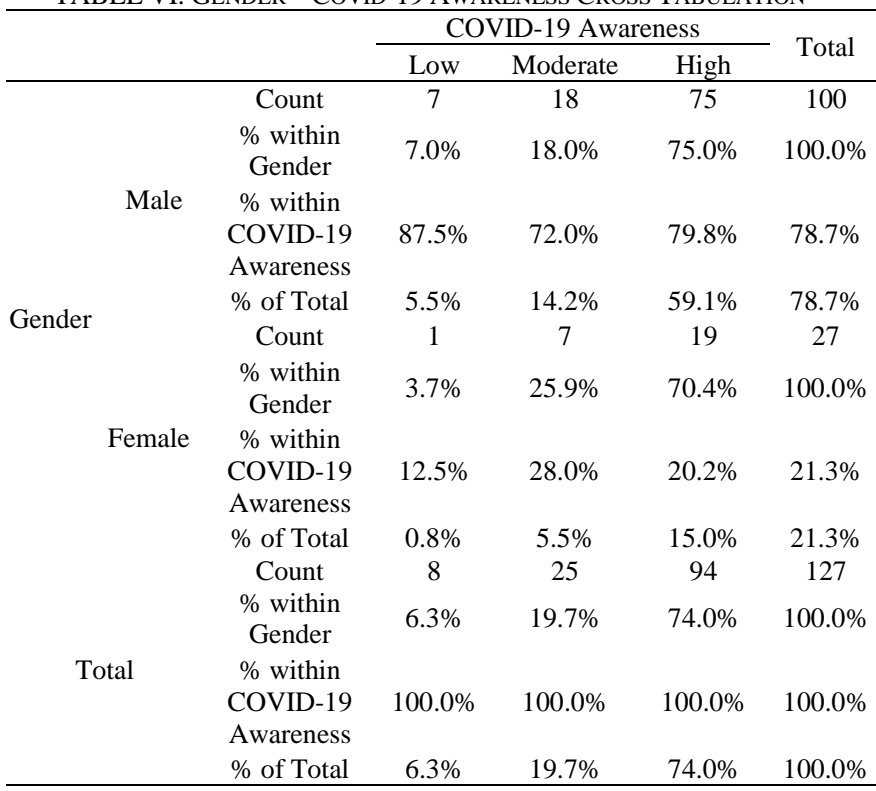

An independent samples t-test was performed to determine if a difference existed between the mean scores of COVID19 knowledges for males and females. The outcome variable was found to be normally distributed and equal variances are assumed based upon results of Levene's test $(\mathrm{F}(125)=0.097$, $\mathrm{p}$-value $=0.756)$. There was no significant difference in knowledge scores (with minimum $=1$, and maximum $=3$ ) for males $($ mean $=1.61$, standard deviation $=0.665)$ and females $($ mean $=1.56$, standard deviation $=0.698 ; \mathrm{t}$ - value $\mathrm{t}(125)$ $=0.374, \mathrm{p}$-value $=0.709$, two-tailed). The magnitude of the difference in the means (mean difference $=0.054,95 \%$ confidence interval: $-0.234,0.343$ ) and the effect size was very small (Cohen $\mathrm{d}=0.08$ ). The independent samples t-test was also performed to test the hypothesis that males and females were associated with statistically significant different COVID-19 awareness mean scores. The test showed no significant difference in the awareness scores for males and females.
TABEL VII: INDEPENDENT SAMPLES TEST KNOWLEDGE OF COVID-19

\begin{tabular}{|c|c|c|c|c|c|c|c|}
\hline \multicolumn{5}{|c|}{$\begin{array}{c}\text { Levene's Test for } \\
\text { Equality of Variances }\end{array}$} & \multicolumn{3}{|c|}{$\begin{array}{c}\text { t-test for Equality of } \\
\text { Means }\end{array}$} \\
\hline & $\mathrm{F}$ & Sig. & $\mathrm{t}$ & $\mathrm{df}$ & $\begin{array}{l}\text { Sig. (2 } \\
\text { tailed) }\end{array}$ & $\begin{array}{l}\text { Mean } \\
\text { Diff. }\end{array}$ & $\begin{array}{c}\text { Std } \\
\text { Error } \\
\text { Diff }\end{array}$ \\
\hline $\begin{array}{c}\text { Equal variances } \\
\text { assumed }\end{array}$ & .097 & .756 & .374 & 125 & .709 & .054 & .146 \\
\hline $\begin{array}{l}\text { Equal variances } \\
\text { not assumed }\end{array}$ & & & .363 & 39.68 & .718 & .054 & .150 \\
\hline
\end{tabular}

\section{Literature and the Review of the Legal Framework:}

The Imposition of Restrictions Act, 2020 (Act 1012) relied on the mandate of the Public Health Act of 2012 (Act 851) Sections169-170:

169 (1): The Minister shall declare a public health emergency by Executive Instrument where there is a situation that poses an immediate risk to health, life property or the environment.

(2) To meet the criteria for a public health emergency, the incident should

(a) immediately threaten life, health, property or the environment;

(b) have already caused loss of life, health detriments, property damage or environmental damage, OR

(c) have a high probability of escalating to cause immediate danger to life, health, property and the environment. Emergency powers in respect of public health matters.

170 (1): The Minister shall direct a public health official to respond immediately to a public health emergency and may order an individual to take preventive measures or be quarantined.

(2) A public health official may be authorized to act outside the area of authority of the public health officer.

If Article 31 of the 1992 Constitution had been used instead, it would have established a more direct and powerful legal basis for the subsequent imposition of restrictions on the people due to the superior position of the constitutional grant. Article 31 (1), (8) and (9) define emergency as:

(1) The President may, acting in accordance with the advice of the Council of State, by Proclamation published in the Gazette, declare that a state of emergency exists in Ghana or in any part of Ghana for the purposes of the provisions of this Constitution.

(8) For the avoidance of doubt, it is hereby declared that the provisions of any enactment, other than an Act of Parliament, dealing with a state of emergency declared under clause (1) of this article shall apply only to that part of Ghana where the emergency exists.

(9) The Circumstances under which a state of emergency may be declared under this article include a natural disaster and any situation in which any action is taken or is immediately threatened to be taken by any person or body of persons which -

(a) is calculated or likely to deprive the community of the essentials of life; or

(b) renders necessary the taking of measures which are required for securing the public safety, the defense of Ghana and the maintenance of public order and of supplies and services essential to the life of the community.

There appears to have been no legal exigency to use Act 
851 Sections 169 and 170 as opposed to using Article 31 Clause (1), (8) and (9) for the declaration of "Health Emergency" since Covid-19 impact on the population was beyond health. Its impact on the economy, society, civil liberties and functioning of the people, called for a declaration of a state of a national emergency. Additionally, it appears the enactment of the Imposition of Restriction Act of 2020, (Act 1012), "to give effect to paragraphs (c), (d) and (e) of Article 21 of the Constitution in the event or imminence of an emergency, disaster or similar circumstances to ensure public safety, public health and protection", was a legal faux pas. This move was superfluous, and at best, it undermined the superior prowess of the 1992 Constitution over all other laws and enactments. It appears to suggest that, Article 21 provisions could not stand 'as is', without the enactment of Act 1012, hence the use of the expression, "to give effect to paragraphs (c) to (e) of Article 21. The enactment of Act 1012 was an improvident and an expensive economic travail that did not add to the quality of the encroachment on the people's liberties, a result which could have been easily achieved under Articles 21 and 31 provisions. It appears the AttorneyGeneral's office, together with the Council of State and the Parliament of Ghana erred by using Article 21 (1) (c), (d) and (e) provisions, as the legal and Constitutional basis for the Imposition of Restrictions Act of 2020. To trigger Article 21 provisions, it is not necessary to employ a lesser legal provision. For Article 21 to be triggered, there first ought to have been an exigent circumstance. Article 21 (1) states that: All persons shall have the right to:

(c) freedom to practice any religion and to manifest such practice

(d) freedom of assembly including freedom to take part in processions and demonstrations

(e) freedom of association, which shall include freedom to form or join trade unions or other associations, national and international, for the protection of their interests;

In order to take away this freedom, there should have been a stronger authority to do so and that a declaration of a public health emergency was not enough legal basis to jump to Article 21 (4) (c), (d) and (e), particularly because the emergency had other dimensions besides health. Article 21 (4) states:

(c) for the imposition of restrictions that are reasonably required in the interest of defense, public safety, public health or the running of essential services, on the movement or residences within Ghana of any person or persons generally, or any class of persons; or

(d) for the imposition of restrictions on the freedom of entry into Ghana, or of movements in Ghana, of a person who is not a citizen of Ghana, or

(e) that is reasonably required for the purpose of safeguarding the people of Ghana against the teaching or propagation of a doctrine which exhibits or encourages disrespect for the nationhood of Ghana, the national symbols and emblems, or incites hatred against other members of the community.

There is no justification from (c), (d) and (e) for depriving the population of the above liberties as articulated under either Article 21 by the impulsively drawn Imposition of Restrictions Act of 2020 on the strength of a public health emergency. The emergency was bigger than health.
Therefore, Article 31 provisions should have been relied on. The declaration of the state of emergency on the 15th of March 2020, by the Minister of Health under the Declaration of Public Health Emergency (Coronavirus Covid-19 Pandemic) E. I. 61 mandate, consistent with the Public Health Act, 2012 (Act 851) Sections 169 and 170, was misplaced from the point of view of the legal framework.

In relation to Response, Protocols and Practices, there are still many gaps although there have been significant achievements, considering the rising daily case numbers of 400 new cases in June of 2020 and the gradual uptick of mortality overall (Ghana Health Service, Home page, 2020). There has been laxity in the initial safety protocols and measures. The partial lockdown of specific parts of the nation stayed in force for only three weeks and during those three weeks, the implementation was haphazardly applied. Although the Ghana Health Service began with aggressive and enhanced contact tracing, testing, quarantine and isolation, and treatment, the current approach is more relaxed [16]. Hospitals and frontline workers still have complaints of the lack of Personal Protective Equipment, PPE and the poor quality of the PPEs being supplied to them [17] This situation may have resulted in some 2,065 of frontline workers, 200 medical doctors getting infected [18], [19].

\section{Imposition of Restrictions Act of 2020, (Act 1012) on the 21st March, 2020}

The Instrument imposed these restrictions on:

(1) (a) public gatherings, including (i) conferences; (ii) workshops; (iii) funerals; (iv) festivals;(v) political rallies; (vi) sporting events and sporting clubs; (vii) private parties and other social gatherings; (viii) night clubs, drinking spots and event centers; and (ix) religious activities in churches, mosques, shrines and at crusades, conventions, pilgrimages and other religious gatherings; and (b) travel to Ghana.

(2) All public gatherings set out in paragraph 1 (1) (a)have been suspended.

(3) Despite paragraph 1 (2), a private burial may be carried out with not more than twenty-five persons in attendance.

(4) All universities and other tertiary institutions, training institutions, senior high schools, basic schools, public and private schools, nurseries, crèches, and such other schools have been closed down.

(5) The Ministry of Education, in collaboration with the Ministry of Communications, may, as far as practicable, run distance learning programs.

Under "Exemptions" the following were delineated:

Exemptions 4. (1)

Paragraph 1 (1) (a) does not apply to the following facilities or establishments:

(a) a service, manufacturing or industrial workplace;

(b) a market;

(c) an establishment in the nature of (i) a supermarket; (ii) a shopping mall; (iii) a restaurant; (iv) a hotel; or (v) a drinking spot; (d) the security services; and (e) essential services.

Notice that the announced exemptions did not prevent the transmission of the disease to the various workplaces of some of the exempted institutions. For example, at least 70 railway workers of a private contractor building Ghana's railway lines, were reported to have been infected with the virus 
(http://www.mrd.gov.gh/4/16/109/coronavirus-hampersrailway-construction-as-over-70-workers-test-positive). From a fish factory in Tema, 533 workers were also infected with the virus. "A single worker at a fish factory in Ghana infected 533 co-workers with coronavirus in an incident that now accounts for roughly 11 percent of the West African country's total recorded infections (https://www.ft.com/content/6dd451ce-e2b7-470f-bf9aa215ccf6c10f). If anything at all, the exempted institutions probably added to the local transmission of the disease.

\section{Executive Instrument, E. I. 65 and 66, 2020.}

Although Executive Instrument, E. I. 65 issued clear the confusion created in the implementation of E. I. 64, it rather added to the challenges of implementation of the previous Executive Instruments on Covid-19. The pertinent portion of E. I. 65 to this paper is the following on streamlining the modalities for the imposition of restrictions:

1) There is imposed, by this Instrument, restrictions on the movement outside the place of abode of person resident within the areas specified in the First Schedule.

The enumerated communities in the First Schedule to E. I. 65 were 26 and 14 in Greater Accra and Kumasi respectively. The communities are a mix of upper class, upper-middle class, middle class and lower classes. Many of the low to poor classes lack basic amenities such as potable supply of water from the City's mains, in-house plumbing and toilets, lack of domestic utensils like refrigeration, individual bathrooms and even kitchens. Many of the residents in some of these communities usually eat or depend on food sold by street vendors situated on the edges of gutters along the city and town streets and thoroughfares [20]. In the Greater Accra area, the communities were: Ablekuma Central Municipality; Ablekuma North Municipality; Ablekuma West Municipality; Accra Metropolis; Adentan Municipality; Ashiaman Municipality; Awutu Senya East Municipality; Ayawaso Central Municipality; Ayawaso East Municipality; Ayawaso North Municipality; Ayawaso West Municipality; Ga Central Municipality; Ga East Municipality; Ga North Municipality; Ga South Municipality; Ga West Municipality; Korle-Klottey Municipality; Kpone Katamanso Municipality; Krowor Municipality; La-Dade-Kotopon Municipality; La-Nkwantanang-Madina Municipality; Ledzokuku Municipality; Okaikwei North Municipality; Tema Metropolis; Tema West Municipality; and Weija/Gbawe Municipality.

In Greater Kumasi Metropolitan Area and contiguous districts, the communities were: Afigya-Kwabre South District; Asokore Mampong Municipality; Asokwa Municipality; Atwima Kwanwoma District; Atwima Nwabiagya Municipality; Atwima Nwabiagya North District; Bosomtwi District; Ejisu Municipality; Kumasi Metropolis; Kwabre East Municipality; Kwadaso Municipality; Oforikrom Municipality; Old Tafo Municipality; and Suame Municipality.

It appears the drafters of the Imposition of Restrictions Act of 2020, (Act 1012) did not think about the needs of the majority of the inhabitants. Therefore, Executive Instrument, E. I. 65 and 66 were, perhaps, drawn to cure the deficiencies of Act 1012. The following was proffered to relax the restrictions on the poor and vulnerable members of those two cities:

2) Despite subparagraph (1), a person may move within the specified areas for the following purposes:

(a) to obtain food, medicine and water;

(b) to undertake banking transactions;

(c) to use public toilet facilities; or

(d) to pay for utility services.

3) The restrictions specified in subparagraph (1) shall apply to inter-city movement of vehicles and aircraft for private or commercial purposes.

4) A rider of a motorbike shall not carry a pillion rider.

5) All intra-city passenger vehicles, including taxis and "tro-tros" shall reduce the number of passengers in order to observe specified social distancing and appropriate enhanced hygiene protocols.

6) All commercial vehicle stations shall observe the specified social distancing and appropriate enhanced hygiene protocols.

From the content analyses conducted, it can be said that the Executive Instruments, perhaps, contributed to only two (2) of the avowed strategy of the government's 5-prong pillars for Covid-19 interventions. With the exception of (i) limiting the importation of the virus and, (iii) the provision of adequate care for the sick, the remaining E. I.s do not appear to have positively contributed to "... (ii) contain its spread, (iv) limit the impact of the virus on social and economic life, and (v) use the opportunity afforded by the emergency to expand our domestic capability and deepen our self-reliance". Between 26 Apr [1,550 cases] and 27 Jun [15,834 cases], the rate of percentage changes with respect to confirmed cases was $921.55 \%$ increase. With a ten (10) days interval from the date Ghana recorded her first case till now, it can be observed from the data above that, there has been a sharp diminishing rate of increase, and as a result, it proves a positive impact of the employed measures. Note, Ghana started off with a rate of change of $950.00 \%$ increase as of 22nd March but has sharply declined to $38.42 \%$ as of 19 th June. Despite the diminishing rate of the rate of increase has reduced per comparison of the figures between 20 May and 19 June with the figures between 12 March and 10 May, the general diminishing rate of the rate of increase between the respective periods is still very significant [21]. Today, Ghana has recorded 40,097 cases, with 36,638 recoveries and 206 deaths [1].

\section{Justification for Executive Instrument, E. I. 164}

By all indications, Executive Instrument, E. I. 164 was issued to cure administrative and implementation challenges of the previous policy strategies articulated to (ii) contain its spread, (iii) provide adequate care for the sick, and (iv) limit the impact of the virus on social and economic life The new addition to the rapidly growing Executive Instruments, E. I. 164 mandated the wearing of face masks, face shield and adherence to hygienic protocols and practices as mandatory. Other more progressive nations had had such policies in place prior to Ghana's adoption. Some of the gaps addressed in this part of this paper came from the gaps identified in the section dealing with the cross-sectional study. These gaps led to the raising of E. I. 164 of 15 June 2020 on the part of government, having noticed, perhaps, earlier on that the previous measures were not effective, considering the uptick of new infections. 
Consequently, E. I. 164 made it mandatory for the population "to wear face masks, face shields or any other face covering that covers his or her nose and mouth completely when the person is in public or leaving or returning to his place of abode". It empowered the police on the beat to make random "checks to ensure enforcement compliances". Those who were caught not wearing face masks would be found to have committed an offence that carries a prison sentence of four to 10 years or a fine of $\mathrm{GH} \phi 12,000$ [USD\$1,791] to $\mathrm{GH} \phi 60,000$, [USD \$8,955] or both. This was to continue for three months. It appears E. I. 164 was an act of desperation on the part of government, and a confirmation that the government was gradually but steadily losing control over the announced Practices and Hygienic Protocols meant to contain the diseases. Part of the failure of this policy was reported to be due to the perceived recalcitrant behavior of the population. But as events in the public space revealed, it was also due to observed nonchalant approach to the practices and protocols by government officials and political party functionaries in the public spaces during official events such as the conduct of a new voter registration by the Electoral Commission of Ghana [22]. Similar non-compliance with Practices and Hygienic Protocols were observed at the registration centers for the National Identification Card. The National ID Card was one of two accepted forms of proof of citizenship to register as a voter. The other form of ID is the Ghanaian passport. Holders of these two cards or one of them are deemed by the Electoral Commission to be citizens and who could vote in general elections.

\section{DISCUSSION}

There appears to have been broad support for government stay at home order, the hygienic protocols and practices among the study participants. The data has provided a snapshot of how the population has related to the diseases and the interventions as well as the restrictions on their civil liberties during the Covid-19 Pandemic. This also shows that the people of Ghana recognize the seriousness of Covid-19 and have generally, accepted government intervention programs such as handwashing, social distancing, face masking wearing and the other hygienic etiquette announced by the Ghana Health Service, Ministry of Health and WHO.

The same cannot be said about government's risk communication modalities and preparedness towards the disease or the equipment and other inputs for clinical interventions as well as policy and legal inputs strategies against the disease. The Executive Instruments raised to address Covid-19, namely (i) Executive Instrument, E. I. 63; (ii) Imposition of Restrictions Act of 2020, (Act 1012) on the 21st March, 2020, with its implementing provision under (iii) Executive Instrument, E. I. 64, 65, 66n and 164, did not deal with the specific issue of Risk Communication as an important aspect of disease surveillance, prevention, management and containment.

The Executive Instruments do not appear to have helped to "limit the impact of the virus on social and economic life". The disease and the actions taken, legal, virological, epidemiological, and others has each not helped the nation to "used the opportunity afforded by the emergency to expand domestic capability and deepen self-reliance". Health facilities in the nation continue to be poorly resourced. Many of the nation's hospitals are not prepared for large Covid-19 cases, resulting in surge demands, and do not possess general emergency preparedness programs. The hospitals' respective abilities to handle large influx of cases or patients are compromised by the lack of competent medical and allied health personnel and adequate supplies. The several stimulus packages announced by the government appears to favor regime favorites and party functionaries in an election year.

On the other hand, some of the interventions appear to "have limited and stopped the importation of the virus" to an impressive extent, although due to the rent-seeking behaviors of some in the security apparatus, occasionally some Covid19 positive persons from neighboring countries manage to enter Ghana on foot. Ghana appears to have "provided adequate care for those with the disease", with a mortality rate of between $0.56 \%$ and $0.62 \%$ depending on who is doing the computation and for what purpose [2].

\section{CONCLUSION}

There is mixed results overall, regarding perceived effectiveness of government and public health programs to contain the disease, limit the spread at the community level, treat those infected, mitigate the impact on the people and use the lessons learned to improve the healthcare delivery system in Ghana. Without a vaccine, the effective way to contain the spread of the disease is through a combination of community adherence to the Social or Physical distancing measures. Additionally, adherence to hygienic protocols and practices, supported by on-going risk communication and good, publicfriendly policies to moderate behaviors in the public space. If the policy or legal framework appears to be too draconian in its implementation as reported in Table 2, the public may react negatively to those public orders. Periodic review of KAP on a bigger scale may help to reveal changes over time and adjustment to risk communication made, to improve public education on Covid-19.

\section{STUDY LiMitATIONS}

This study has a number of limitations, namely, the webbased sampling method, the small sample size, the selfreporting nature of the questionnaire, creating the possibility that, the responses and the social desirability measures may be biased. The majority of the respondents had some form of tertiary, post-secondary school education, such as HND, Bachelors, Masters and Ph.D., except $6.3 \%$ of the cohort that did not. This weakness may skew the result to one direction, whiles ignoring the input of the majority of the people of Ghana that do not have such antecedents. The study is not representative of Ghana, even though the cohort came out of twelve of the sixteen administrative districts of Ghana, due to, among others, the web-based sampling method used. This approach denies the use of population-based probability sampling method for a more representative cross-sectional survey. For example, $90.6 \%$ of the respondents were Christians, with only $5.5 \%$ being Muslims. The rest were Traditional believers $1.6 \%$, and those who self-described as 
non-religious or None being $0.8 \%$ and $1.6 \%$ respectively. The percentage representation of Muslims in Ghana is estimated to be between 10 and $20 \%$ of the overall population. For these reasons, this survey may not be generalized to the rest of the nation without stating these caveats. The study is still useful in understanding the role of risk population, social distancing and hygienic practices and protocol in mitigating the spread, containment, treatment and social mitigation against Covid19. In terms of the legal framework, it provides an insightful excursion into law and policy formulation during a public health emergency in Ghana, which is instructional to other common law nations in Africa south of the Sahara.A conclusion section is not required. Although a conclusion may review the main points of the paper, do not replicate the abstract as the conclusion. A conclusion might elaborate on the importance of the work or suggest applications and extensions.

\section{ACKNOWLEDGMENT}

We are grateful to Blandina Martin Awiah-Norman for assisting in the preparation and proofreading of several drafts of this paper. Any error however in this paper is attributable only to the authors.

\section{REFERENCES}

[1] Ghana's Covid-19 Mortality Rate, Ghana Health Service, www.coronatracker.com/gh. (accessed 8/8/2020).

[2] Okoe Boye. 2020. Ghana's Covid-19 Story: An Analysis of, Facts, Figures and Fiction, Ministry of Health, download1594808111752.docx, 13/7/2020.

[3] Adnan M., Khan S., Kazmi A. COVID-19 infection: Origin, transmission, and characteristics of human coronaviruses. J Adv Res. 2020;24:91-98. - PMC - PubMed.

[4] World Health Organization. Coronavirus disease 2019 (COVID-19): Situation report- 19. [internet]. WHO; 2020. Available from: https://www.who.int/docs/default-source/coronaviruse/situationreports/ 20200420-sitrep-91-covid-19.pdf?sfvrsn=fcf0670b 4.

[5] Nana Addo Danquah so Addo. 2020. National Response Plan for Covid-19. SONA, 15/3/2020, www.myjoyonline.com.

[6] Mizumoto, K; Kagaya, K; and Chowell, G. 2020. Early Epidemiological Assessment of the Transmission Potential and Virulence of Coronavirus Disease 2019 (Covid-19) in Wuhan City, China, January - February, 2020. BMC Medicine, 2020, July, 18:217. https// doi.org/10.1186/s12916-020-01691-x.

[7] Phan LT, Nguyen TV, Luong QC, Nguyen TV, Nguyen HT, Le HQ, et al. Importation and human-to-human transmission of a novel coronavirus in Vietnam. N Engl J Med. (2020) 382:872-4. DOI: 10.1056/NEJMc2001272.

[8] Slovic, P. 2000b. "Informing and Educating the Public about Risk," in P. Slovic (ed.) The Perception of Risk, Earthscan: Sterling, VA, 192198.

[9] Glik, D. C. 2007. Risk Communication for Public Health. Annual Rev. Pub Health, 28:33-54.

[10] Norman, I. D., Aikins, M., Binka, F. N., and Godi, T. H. 2012. Review of Ghana's 2009-2013 Integrated Strategic Response Plan for Pandemic Influenza: Illustrative study of the Perceived Adequacy of Preparedness for the Pandemic Influenza of Sub-Sahara Africa. British Medical Journal/Emergency Medicine Journal.

[11] Norman, I. D, Aikins, M, Binka, F. N, Blandina Awiah. 2015. Review of Catastrophic Fires and Risk Communication, Ghana. Advances in Applied Sociology, 2015.

[12] Perry, R. W., and Lindell, M.K. (1991). "The Effects of Ethnicity on Evacuation Decision-Making," International Journal of Mass Emergencies and Disasters, March, 9(1), 47-68.

[13] Flynn, J. Slovic, P., Mertz, C.K., and Carlisle, C. 1999. Public Support for Earthquake Risk Mitigation in Portland, Oregon. Risk Analysis, 19(2), 205-216.

[14] Fischhoff, B. 2002. Risk Perception, Risk Communication, Risk Taking. Journal of Psychology and Financial Markets, 3:102-111.
[15] Quarantelli, E. L. 1989. "How Individuals and Groups React during Disaster: Planning and Managing Implications for EMS Delivery", Quoting Regler, Darrel A. et al., Archives of General Psychiatry, 45 977-986, 1989, University of Delaware, Wilmington, Delaware., USA

[16] Nsiah Asare. 2020. Mass testing will not reduce spread of coronavirus -, www.citinewsroom.com, 27th June 2020, retrieved 12 July 2020.

[17] World Health Organization. Shortage of personal protective equipment endangering health workers worldwide. [internet]. Geneva: WHO 2020 Mar 3 [updated 2020 Mar 3; cited 2020 July 10]. Available from: https://www.who.int/news-room/detail/03-03-2020-shortage-ofpersonal-protective-equipmentendangering-health-workersworldwide.

[18] GHS: 2,065 Health Workers Test Positive, Patrick Kuma-Aboagye, 16/7/2020, https://www.ghanaweb.com/Ghana.

[19] Over 770 health workers contract Covid-19 due to lack of PPEs-Health Workers Union, www.myjoyonline.com, 9 July 2020, retrieved 12 July 2020.

[20] Patricia Foriwaa Ababio and Pauline Lovatt. 2015. A review on food safety and food hygiene studies in Ghana. Food Control 47:92-97, DOI: 10.1016/j.foodcont.2014.06.041.

[21] Akwaa, K. K. 2020. Ghana performing better with Covid-19 management, mathematical facts, figures and analysis. Accra, Ghana.

[22] Health Workers Talk EC: Voter Registration: Pause voter Registration exercise to prevent more Covid-19 deaths, www.bbc.com/africa/news, $6 / 7 / 2020$.

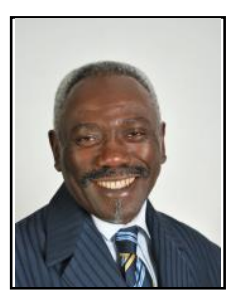

Dr. Ishmael D. Norman is currently the President and CEO of the Institute for Security, Disaster and Emergency Studies. He was the Director for West Africa and Co-PI for the USAID sponsored Resilient Innovation Lab (RiLab/Higher Education Solutions Network) housed at the University of Health and Allied Sciences, Ho, Volta Region, Ghana. The project was in collaboration with the Center for Strategic and International Studies, Stanford University, Disaster Resilient Leadership Academy, Tulane University. The School of Public Health, Makerere University was the Prime. Ishmael was also the PI and Director for West Africa in the Strengthen Leadership for Disaster Resilience Program with DRLA, Tulane University. Dr. Norman was the Head of Department at the Department of Biological, Environmental and Occupational Health Sciences at the School of Public Health, University of Ghana from 2010 through March 2013, where he taught public health legislation, occupational and environmental health sciences and public health ethics. Dr. Ishmael D. Norman holds a PH. D in Public Health from the University of Ghana and Juris Doctor degree from the University of New Hampshire's Franklin Pierce Law Center.

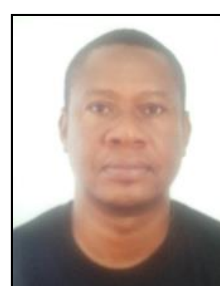

Emmanuel D. Kpeglo received the M.Sc. in Mathematics degree from the Kwame Nkrumah University of Science and Technology and currently a Ph.D. in Statistics student at the University for Development Studies. Emmanuel teaches several courses in Mathematics and Statistics. He is a Lecturer of Research Methodology at the Institute of Security, Disaster and Emergency Studies. He has been involved in several collaborative research projects.

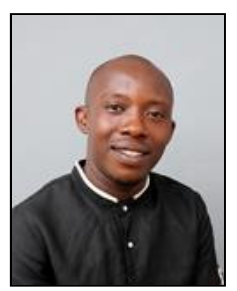

Raymond Agalga is a Ghanaian Research Scientist with years of experience in Nuclear Safety, Security, Safeguards and Non-Proliferation related science.

He has vast experience in emergency response situation as far as nuclear related incidents are concerned. Raymond has lectured and attended various international and national meetings on emergency response, Boarder security and on the Physical Protection on Nuclear Materials. He has also participated in numerous IAEA sponsored projects on security culture enhancement solutions, insider threat preventative and protective Measures. Raymond is Currently a PhD student at the Department of Physics Kwame Nkrumah University of Science and Technology.

$\mathrm{He}$ is Certified Nuclear Security Professional and a Member of ASIS International 